\title{
Rhinology in the forefront of European political attention
}

On Oct. 14, 2015, a symposium on Precision Medicine in Allergy and Airways Diseases took place in the European Parliament in Brussels. The burden of disease in patients with rhinitis and rhinosinusitis was brought to the attention of European policy makers and different stakeholders involved in patient care, highlighting the high prevalence of allergic rhinitis and rhinosinusitis reaching epidemic proportions ${ }^{(1,2)}$, the major socio-economic consequences ${ }^{(3,4)}$ and the impact uncontrolled disease despite evidence-based treatment ${ }^{(5,6)}$. The Commissioner of Health and Food Safety of Europa, Vytenis Andriukaitis, as well as the presidents of large European Academies and Associations agreed upon the fact that a joint action plan is needed to arrest the epidemic of allergy and chronic airways diseases in Europe via joining forces between patient organizations, health care professionals and researchers. The European Rhinologic Society was one of the organisers of the symposium and highlighted the often overlooked burden of upper airway diseases like allergic and non-allergic rhinitis and rhinosinusitis with or without nasal polyps ${ }^{(7,8)}$. Precision Medicine, a novel medical approach combining personalized care with prevention of disease ${ }^{(1,9)}$, prediction of success of treatment ${ }^{(10,11)}$ and participation of the patient in the therapeutic approach ${ }^{(7,12)}$, is at the forefront of the European action plan. The implementation of the principles of Precision Medicine in best practise centers in Europe will be a major step forward to arrest the Epidemic of Allergy and Chronic Airways Diseases. The Finnish Allergy and Asthma Programme has been very successful in the reduction of the prevalence and burden of allergic diseases and asthma, and should therefore be considered for dissemination in Europe ${ }^{(13,14)}$. Recent data from the UK suggest that early (surgical) intervention in chronic rhinosinusitis may improve long term clinical outcomes regardless of comorbid lower airway disease $(15,16)$ also pointing to a role for secondary prevention. Hope arises at the horizon for our patients.

\section{References}

1. Hox V, Steelant B, Fokkens W, Nemery B, Hellings PW. Occupational upper airway disease: how work affects the nose. Allergy. 2014;69(3):282-91.

2. Hastan D, Fokkens WJ, Bachert C, Newson RB, Bislimovska J, Bockelbrink A, et al. Chronic rhinosinusitis in Europe--an underestimated disease. A GA(2)LEN study. Allergy. 2011;66(9):1216-23.

3. Smith KA, Orlandi RR, Rudmik L. Cost of adult chronic rhinosinusitis: A systematic review. Laryngoscope. 2015;125(7):1547-56.

4. Cibella F, Ferrante G, Cuttitta G, Bucchier S, Melis MR, La Grutta S, et al. The burden of rhinitis and rhinoconjunctivitis in adolescents. Allergy, Asthma Immunol Res. 2015;7(1):44-50

5. Hellings PW, Fokkens WJ, Akdis C, Bachert C Cingi C, Dietz de Loos D, et al. Uncontrolled allergic rhinitis and chronic rhinosinusitis: where do we stand today? Allergy. 2013;68(1):1-7.

6. Prokopakis EP, Vlastos IM, Ferguson BJ Scadding G, Kawauchi H, Georgalas C, et al. SCUAD and chronic rhinosinusitis. Reinforcing hypothesis driven research in difficult cases. Rhinology. 2014;52(1):3-8.

7. Bousquet J, Addis A, Adcock I, Agache I, Agusti A, Alonso A, et al. Integrated care pathways for airway diseases (AIRWAYSICPs). Eur Resp J. 2014;44(2):304-23.

8. Zuberbier T, Lotvall J, Simoens $S$, Subramanian SV, Church MK. Economic burden of inadequate management of allergic diseases in the European Union: a GA(2) LEN review. Allergy. 2014;69(10):1275-9.
9. Muraro A, Halken S, Arshad SH, Beyer K, Dubois AE, Du Toit G, et al. EAACl food allergy and anaphylaxis guidelines. Primary prevention of food allergy. Allergy. 2014;69(5):590-601.

10. Hopkins C, Philpott C, Crowe S, Regan S, Degun A, Papachristou I, et al. Identifying the most important outcomes for systematic reviews of interventions for rhinosinusitis in adults: working with Patients, Public and Practitioners. Rhinology 2016. in press.

11. Minwegen F, Thomas JP, Bernal-Sprekelsen M, Dazert S, Minovi A. Predictive value of disease severity on self-reported rating and quantitative measures of olfactory function outcomes after primary endoscopic sinus surgery. A prospective study. Rhinology. 2014;52(4):437-43

12. Fokkens WJ. Patient-centered treatment goals. Rhinology. 2013;51(3):193-4.

13. Pelkonen AS, Kuitunen M, Dunder T, Reijonen T, Valovirta E, Makela MJ. Allergy in children: practical recommendations of the Finnish Allergy Programme 20082018 for prevention, diagnosis, and treatment. Pediatr Allergy Immunol. 2012 Mar;23(2):103-16.

14. von Hertzen LC, Savolainen J, Hannuksela M, Klaukka T, Lauerma A, Makela MJ, et al. Scientific rationale for the Finnish Allergy Programme 2008-2018: emphasis on prevention and endorsing tolerance. Allergy. 2009;64(5):678-701.

15. Hopkins C, Andrews P, Holy CE. Does time to endoscopic sinus surgery impact outcomes in chronic rhinosinusitis? Retrospective analysis using the UK clini- cal practice research data. Rhinology. 2015;53(1):18-24

16. Hopkins C, Rimmer J, Lund VJ. Does time to endoscopic sinus surgery impact outcomes in Chronic Rhinosinusitis? Prospective findings from the National Comparative Audit of Surgery for Nasal Polyposis and Chronic Rhinosinusitis. Rhinology. 2015;53(1):10-7.

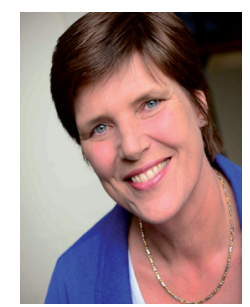

Wytske J. Fokkens, Editor-in Chief Amsterdam, the Netherlands

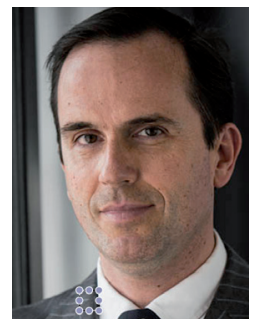

Peter W. Hellings, Associate Editor

Amsterdam, the Netherlands Leuven, Belgium 